\title{
PHYLOGENETIC TAXONOMY OF ARTEMISIA L. SPECIES FROM KAZAKHSTAN BASED ON MATK ANALYSES
}

\author{
Yerlan Turuspekov ${ }^{1,5}$, Yuliya Genievskaya ${ }^{1}$, Aida Baibulatova ${ }^{1}$, Alibek Zatybekov ${ }^{1}$, \\ Yuri Kotuhov ${ }^{2}$, Margarita Ishmuratova ${ }^{3}$, Akzhunis Imanbayeva ${ }^{4}$, and Saule Abugalieva ${ }^{1,5, \#}$ \\ ${ }^{1}$ Institute of Plant Biology and Biotechnology, 45 Timiryazev Street, Almaty, KAZAKHSTAN \\ ${ }^{2}$ Altai Botanical Garden, Ridder, KAZAKHSTAN \\ ${ }^{3}$ Karaganda State University, Karaganda, KAZAKHSTAN \\ ${ }^{4}$ Mangyshlak Experimental Botanical Garden, Aktau, KAZAKHSTAN \\ ${ }^{5}$ Al-Farabi Kazakh National University, Biodiversity and Bioresources Department, Almaty, KAZAKHSTAN \\ \# Corresponding author, absaule@yahoo.com
}

\section{Communicated by Isaak Rashal}

\begin{abstract}
The genus Artemisia is one of the largest of the Asteraceae family. It is abundant and diverse, with complex taxonomic relations. In order to expand the knowledge about the classification of Kazakhstan species and compare it with classical studies, matK genes of nine local species including endemic were sequenced. The infrageneric rank of one of them (A. kotuchovii) had remained unknown. In this study, we analysed results of sequences using two methods - NJ and MP and compared them with a median-joining haplotype network. As a result, monophyletic origin of the genus and subgenus Dracunculus was confirmed. Closeness of A. kotuchovii to other species of Dracunculus suggests its belonging to this subgenus. Generally, matK was shown as a useful barcode marker for the identification and investigation of Artemisia genus.
\end{abstract}

Key words: Artemisia, Artemisia kotuchovii, DNA barcoding, haplotype network.

\section{INTRODUCTION}

Artemisia of the family Asteraceae is a genus with great economic potential and importance. Species of this genus have been used in many aspects of life throughout the course of history (Lachenmeier, 2010; Petrovska, 2012). They have been used as medicinal, food, and ornamental plants (Weathers et al., 2011). A number of species have a very important medicinal significance, especially Artemisia аппиа L. (Klayman, 1985) and Artemisia absinthium L. (Lachenmeier, 2010). One of the most common examples is tarragon - A. dracunculus L. It is widespread in the wild across much of Eurasia and North America, and is cultivated for culinary and medicinal purposes. Its essential oils are used as antibacterial agents; dry leaves are added as flavourings for meat and fish (Aglarova et al., 2008; Obolskiy et al., 2011).

Of the family Asteraceae, the tribe Anthemideae, genus $A r$ temisia is one of the largest genera (Bremer and Humphries, 1993; Oberpreiler et al., 1995). It includes about 500 species, which are distributed in five subgenera (Vallčs and McArthur, 2001). Species of this genus are widespread in the Northern Hemisphere, particularly in Eurasian temperate zone and North America, and in South and North Africa
(Bremer, 1994; Torrel et al., 1999). Due to the large amount of species in the genus, their classification is still complex and not fully completed. In earlier studies, the genus was subdivided into three subgenera (Poljakov, 1961; Kornkven et al., 1998). Absinthium and Tridentatae subg. were considered as the sections of Artemisia and Seriphidum subg., respectively. In more recent work already four subgenera were declared (Persson et al., 1974). Absinthium was proposed as a separate subgenus originated from the Artemisia subg. Based only on the capitula type and florets fertility, five major groups described as subgeneric or sectional rank (Absinthium, Artemisia, Dracunculus, Seriphidium, and Tridentatae) are more or less constantly found in classic studies confirmed by molecular data (Torrel et al., 1999). Previous phylogenetic studies on Artemisia showed monophyly of the genus and monophyly of the three main infrageneric groups (Dracunculus, Seriphidium, Tridentatae), whereas subgenera Absinthium and Artemisia were described as polyphyletic (Watson et al., 2002). Classical subgeneric separation based only on morphological traits was rearranged, because in some cases it was not supported by the traditional classifications (Sanz et al., 2008; Tkach et al., 2008). Moreover, processes such as hybridisation, introgression, and polyploidisation are very common for these plants 
and this makes understanding of their relations at the molecular level even more difficult (Winward and McArthur, 1995).

Central Asia is a centre of the genus Artemisia origin and one of the most important centres of its diversification (McArthur and Plummer, 1978; Wang, 2004). According to previous studies, most of the Asian species belong to the Seriphidium subg. (Poljakov, 1961; Tkach et al., 2008). In Kazakhstan, there are around 80 species mostly growing in steppes and deserts (Pavlov et al., 1966). In general, endemic and rare species of the genus Artemisia in Kazakhstan are poorly studied and their place in subgenera classification is not well described. Only a few works were dedicated to their biochemistry and economical importance (Goryaev et al., 1962; Nikitina et al., 1964). The main aim of our study was to reveal the complex relations of subgenera in the genus Artemisia growing in Kazakhstan and compare results with traditional classifications based on both morphological traits (Poljakov, 1961) and molecular data (Watson et al., 2002; Sanz et al., 2008; Garcia et al., 2011). Another important objective was to determine the place of one unranked local species - A. kotuchovii — in the subgenera classification. Additionally, we tested two different methods for phylogenetic taxonomy (joining and maximum parsimony) and compared them to haplotype networking analysis.

This work represents a new direction in the study of Kazakhstan native flora. In the past, only a few reports were related to the description of the genetic variation of local flora (Adams et al., 1998; Turuspekov et al., 2002). Therefore, the study is an expansion of a research oriented towards description of endemic, rare, and economically important species of the country and part of cooperative nation-wide project (Turuspekov and Abugalieva, 2015) for genotyping of plant accessions using DNA barcoding. The project combined efforts of local botanists and geneticists from biotechnology research organisations, botanical gardens, state nature parks, and reserves. In the last 20 years, DNA barcoding has shown itself as a powerful and efficient tool for sample identification and phylogeny of new and poorly studied species (Hebert et al., 2003; Hebert et al., 2005; Kress et al., 2017).

\section{MATERIALS AND METHODS}

Materials sampling. Nine populations of Artemisia species were collected from different places of central, southeastern, eastern, and western regions of Kazakhstan (Table 1, Fig. 1). For the reconstruction of intragenus topology sequences of twenty one Artemisia taxa were taken from GenBank (https://www.ncbi.nlm.nih.gov/genbank/).

DNA extraction, amplification and sequencing. Three plants from each population were chosen for the genetic analysis. Total genomic DNA was extracted from dry leaf material according to the modified Dellaporta DNA extraction protocol (Dellaporta et al., 1983). Individual DNA samples were analysed separately. PCR fragments were amplified for the maturase $\mathrm{K}$ gene of the chloroplast genome (matK) (Naeem et al., 2014).

All PCR reactions were carried out in $16 \mu \mathrm{l}$ volumes in a Veriti Thermo cycler (Applied Biosystems, Foster City, CA, USA). One PCR reaction contained $4 \mathrm{mM}$ of each dNTP, $6.4 \mathrm{mM}$ of primer mix, $1.6 \mathrm{U}$ of Taq DNA polymerase and $80 \mathrm{ng}$ of total genomic DNA. Protocols for PCR reactions were taken from Jun et al. (2012). Primers chosen for PCR included matK-F

(5'-CCTATCCATCTGGAAATCTTAG-3') and matK-R (5'-GTTCTAGCACAAGAAAGTCG-3') with annealing

LIST OF ARTEMISIA SPECIES COLLECTED IN KAZAKHSTAN AND THEIR GENBANK ACCESSIONS NUMBERS

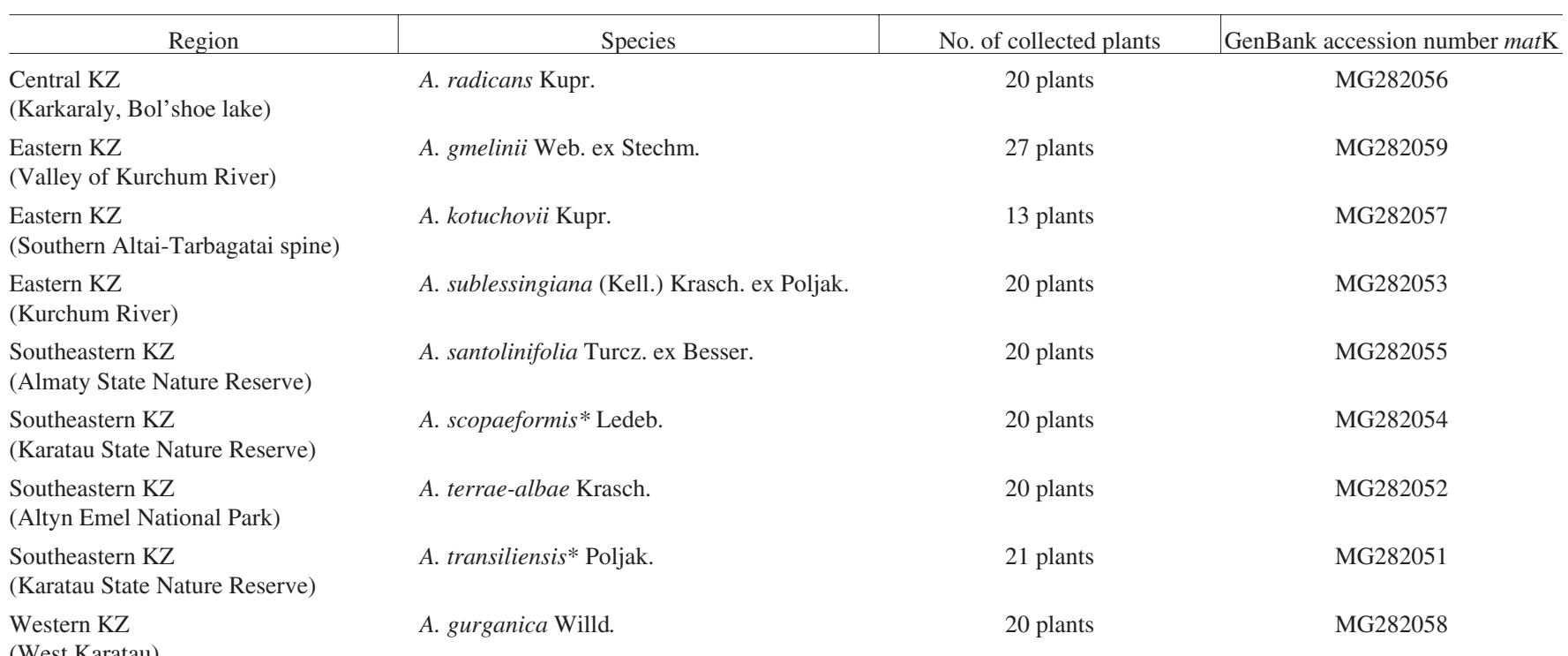

\footnotetext{
* indicates endemic species for the Kazakhstan territory (Pavlov et al., 1966).
} 


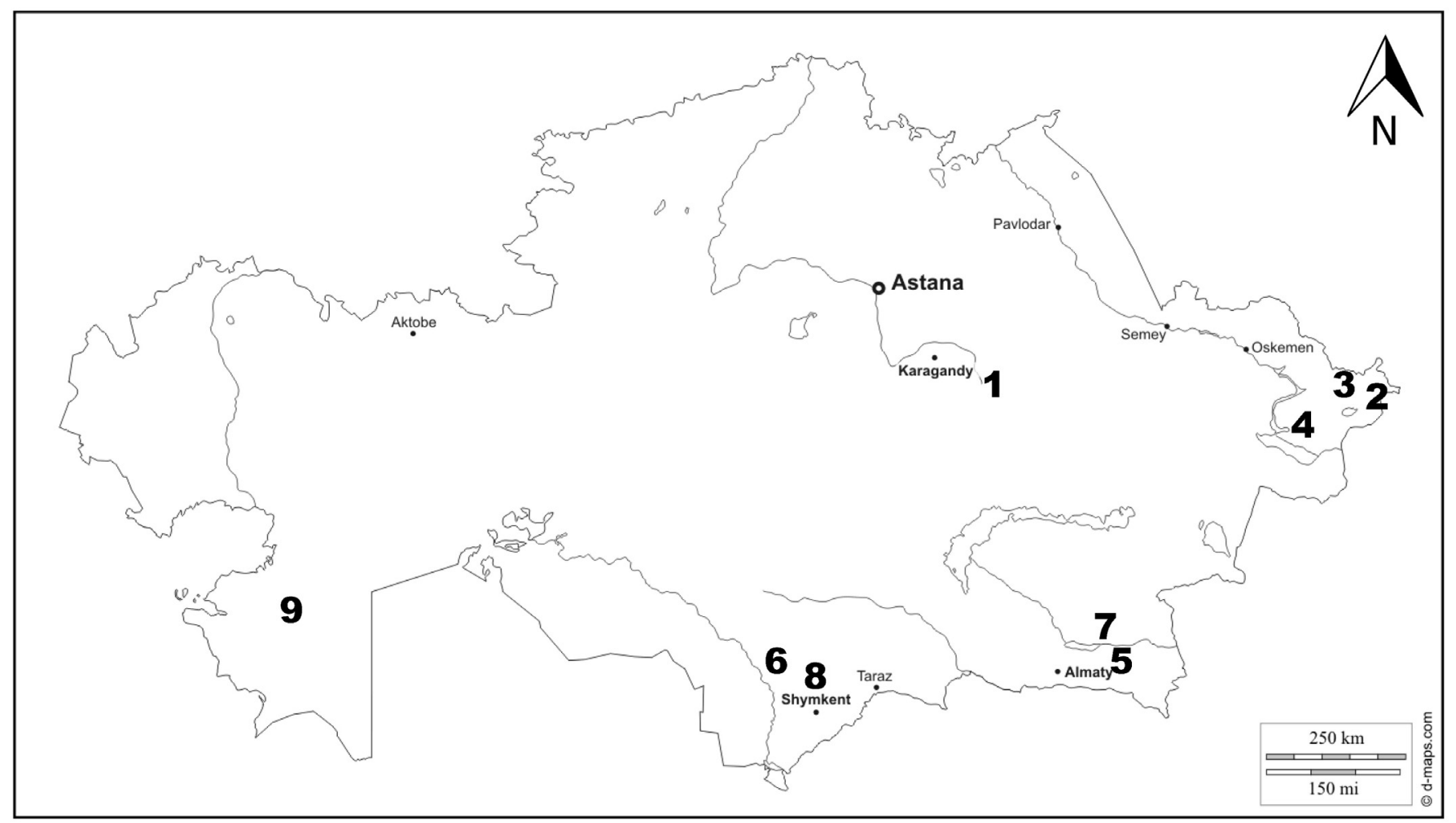

Fig. 1. Collected sites of Artemisia species.

One number denotes sampling point for the population of one species: 1 - A. radicans Kupr.; 2 - A. gmelinii Web. ex Stechm.; 3 - A. kotuchovii Kupr.; 4 A. sublessingiana (Kell.) Krasch. ex Poljak.; 5 - A. santolinifolia Turcz. ex Besser.; 6 - A. scopaeformis* Ledeb.; 7 - A. terrae-albae Krasch.; 8 A. transiliensis* Poljak.; 9 - A. gurganica Willd. * Indicates endemic plants for Kazakhstan territory (Pavlov et al., 1966).

temperature $50{ }^{\circ} \mathrm{C}$ and expected sizes of amplicons $784 \mathrm{bp}$ (obtained from Asterales according to GenBank data).

Whole volume of each PCR product was checked by electrophoresis in $1.5 \%$ agarose gel at $80 \mathrm{~V}$ voltage for $40 \mathrm{~min}$. Single bands with expected sizes for matK were visualised, cut out from gel and purified using the ULTRAPrep® Agarose Gel Extraction Mini Prep Kit (AHN Biotechnologie $\mathrm{GmbH}$, Nordhausen, Germany) according to the protocol provided by the company. Purified DNA amplicons were used for the sequence reactions with forward and reverse primers separately. All reactions were performed with the BigDye Terminator Cycle Sequencing technology (Applied Biosystems, Foster City, CA, USA) according to protocols of the company.

Alignment and phylogenetic analyses. Generated matK sequences of the samples were imported in MEGA 6 (Tamura et al., 2013) software. Results were evaluated by different methods used for phylogenetic reconstructions neighbour-joining (Bhattacharyya, Mukherjee, 2017) and maximum parsimony (Bryant et al., 2017).

The final alignment was imported into DNASP v5.10 (Librado and Rozas, 2009) and converted into Roehlfile format for the operations in the Network software (version 4.6; http://fluxus-engineering.com). In addition, the nucleotide sequences for matK of local species were aligned with sequences of Artemisia species from the NCBI reference data- base. The genetic structure was assessed through medianjoining haplotype networks (Bandelt et al., 1999) using the Network software. Post-processing calculation was done without the MP criterion $(\varepsilon=0)$.

\section{RESULTS}

DNA sequencing. DNA sequences of $784 \mathrm{bp}$ of the maturase $\mathrm{K}$ gene (mat $\mathrm{K})$ were obtained from nine local Artemisia species and aligned in MEGA 6.06 together with available Artemisia references from the GenBank. Tanacetum parthenium L., Achillea ptarmica L., and Anthemis cotula L. from the same tribe Anthemideae (Asteraceae) were chosen as the outgroups. In total, 9 sites with gaps and 17 polymorphic sites were detected for the studied Artemisia species. Nine of those sites were singleton variable sites and other eight were parsimony informative sites (Fig. 2). In this study we used two sets of data: 1) Kazakhstan species with specimens from Genbank; 2) Kazakhstan species only. There were no differences among DNA sequences in analysed three individual plants within nine studied species from Kazakhstan. The sequences of matK of the nine species were deposited to the NCBI database (Table 1).

Phylogenetic and haplotype network analyses of local species and GenBank specimens. The first tree was reconstructed using the NJ method (bootstrap 1000) for 33 species, including outgroups (Fig. 3). All species of the genus 


\begin{tabular}{|c|c|c|c|c|c|c|c|c|c|c|c|c|c|c|c|c|c|c|c|c|c|c|c|c|c|c|}
\hline $\begin{array}{l}\text { Noo } \\
\text { Nucleotide position }\end{array}$ & $\begin{array}{c}1 \\
147\end{array}$ & $\begin{array}{c}2 \\
170\end{array}$ & $\begin{array}{c}3 \\
216\end{array}$ & $\begin{array}{c}4 \\
233 \\
\end{array}$ & $\begin{array}{c}5 \\
258 \\
258\end{array}$ & $\begin{array}{c}6 \\
259\end{array}$ & $\begin{array}{c}7 \\
260\end{array}$ & $\begin{array}{c}8 \\
261\end{array}$ & $\begin{array}{c}9 \\
262 \\
\end{array}$ & $\begin{array}{r}10 \\
263\end{array}$ & $\begin{array}{c}11 \\
264\end{array}$ & $\begin{array}{c}12 \\
265\end{array}$ & $\begin{array}{l}13 \\
266\end{array}$ & $\begin{array}{c}14 \\
278\end{array}$ & $\begin{array}{c}15 \\
280\end{array}$ & $\begin{array}{c}16 \\
350\end{array}$ & $\begin{array}{l}17 \\
404\end{array}$ & $\begin{array}{c}18 \\
421\end{array}$ & $\begin{array}{l}19 \\
445\end{array}$ & $\begin{array}{c}20 \\
473\end{array}$ & $\begin{array}{l}21 \\
507\end{array}$ & $\begin{array}{c}22 \\
511\end{array}$ & $\begin{array}{c}23 \\
537\end{array}$ & $\begin{array}{l}24 \\
602\end{array}$ & $\begin{array}{r}25 \\
611\end{array}$ & $\begin{array}{c}26 \\
632\end{array}$ \\
\hline KJ372399.1 Artemisia roxburghiana* & G & c & A & A & c & $\mathrm{T}$ & $\mathrm{T}$ & $\mathrm{G}$ & $\mathrm{c}$ & A & G & A & A & $G$ & c & $T$ & $\mathrm{c}$ & $\mathrm{T}$ & G & $\mathrm{T}$ & G & $\mathrm{G}$ & $\mathrm{c}$ & $\mathrm{T}$ & G & G \\
\hline KF648716.1 Artemisia vulgaris* & $\mathrm{T}$ & . & $G$ & . & . & . & . & & . & . & . & . & . & . & . & . & . & A & & . & . & . & . & . & . & . \\
\hline JQ412200.1 Artemisia afra* & $\mathrm{T}$ & . & G & . & . & . & . & & . & . & . & . & . & . & . & . & . & A & . & . & . & . & . & . & . & . \\
\hline Artemisia radicans & $\mathrm{T}$ & . & G & . & & . & . & & . & . & . & . & . & . & . & . & . & A & & . & . & . & . & . & . & . \\
\hline Artemisia sublessingiana & $\mathrm{T}$ & . & G & . & & . & . & & & & & . & . & . & . & . & . & A & & & & & . & . & & . \\
\hline Artemisia scopaeformis & $\mathrm{T}$ & . & G & . & & . & . & . & . & . & & . & . & . & . & . & . & A & . & . & . & & . & & & . \\
\hline Artemisia transiliensis & $\mathrm{T}$ & . & G & . & & . & . & . & . & . & & . & . & . & . & . & . & A & . & . & . & & . & . & & . \\
\hline GQ434109.1 Artemisia gmelinii* & $\mathrm{T}$ & . & G & . & . & . & . & . & . & . & . & . & . & . & . & . & . & A & . & . & . & . & . & . & . & . \\
\hline FN668458.1 Artemisia arctisibirica* & $\mathrm{T}$ & . & G & . & . & . & . & & . & . & . & . & . & . & . & . & . & A & & . & . & . & . & . & . & . \\
\hline JQ173391.1 Artemisia sieversiana* & $\mathrm{T}$ & . & G & . & . & . & . & & . & . & . & . & . & . & . & . & . & A & & . & . & . & . & . & & . \\
\hline $\begin{array}{l}\text { KC474124.1 Artemisia borealis subsp. } \\
\text { richardsoniana* }\end{array}$ & $\mathrm{T}$ &. & $G$ & . & . & . & . & & . & . & 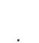 &. & & c & & . & & A & & . &. & . & & . & C & \\
\hline JQ173388.1 Artemisia capillaris* & $\mathrm{T}$ & & G & . & & . & . & & . & . & & . & . & $\mathrm{c}$ & . & & & A & & . & . & & . & & c & . \\
\hline HM989797.1 Artemisia scoparia* & $\mathrm{T}$ & . & G & . & & & & & & & & . & . & c & . & . & . & A & & & & & . & . & c & . \\
\hline JN894047.1 Artemisia campestris* & $\mathrm{T}$ & . & G & . & & . & . & & . & . & . & . & . & $\mathrm{c}$ & . & . & . & A & & . & . & . & . & . & c & . \\
\hline KC474133.1 Artemisia tilesii ${ }^{*}$ & $\mathrm{~T}$ & . & G & . & . & . & . & & . & . & . & . & . & . & . & . & . & A & . & . & . & . & . & . & . & A \\
\hline JQ173387.1 Artemisia annua* & $\mathrm{T}$ & . & G & . & . & . & . & & . & . & . & . & . & . & . & . & . & A & & . & . & . & . & . & r. & A \\
\hline JQ173390.1 Artemisia sacrorum* & $\mathrm{T}$ & . & G & . & . & . & . & & . & . & . & . & . & . & . & . & . & A & & . & . & . & . & . & . & A \\
\hline KC474129.1 Artemisia hyperborea (A. furcata)* & $\mathrm{T}$ & A & G & . & & . & . & . & . & . & & . & . & & . & & & A & . & . & . & & . & & & . \\
\hline HM989729.1 Artemisia lactiflora* & $\mathrm{T}$ & & G & & - & - & - & - & - & - & - & - & - & & & & & A & . & . & . & & & & & . \\
\hline HM989726.1 Artemisia argyi* & $\mathrm{T}$ & . & G & . & - & - & - & - & - & - & - & - & - & & . & . & & A & & & & & . & & & \\
\hline JN894044.1 Artemisia absinthium* & $\mathrm{T}$ & . & G & . & . & . & . & & . & . & . & . & . & . & . & . & . & A & . & . & T & A & . & G & & \\
\hline HQ593182.1 Artemisia dracunculus* & $\mathrm{T}$ & & $G$ & c & . & . & . & & . & . & . & . & . & . & . & . & . & A & A & G & . & . & . & . & c & . \\
\hline AF456776.1 Artemisia tridentata* & $\mathrm{T}$ & A & G & . & . & . & . & & . & . & . & . & . & . & . & . & . & A & & . & . & . & A & . & . & . \\
\hline Artemisia gurganica & $\mathrm{T}$ & & G & . & & . & . & & . & . & & . & & & . & & A & A & . & . & . & & & & & . \\
\hline Artemisia terrae-albae & $\mathrm{T}$ & & G & & & . & . & & . & . & & & & & & & A & A & & . & & & & & & \\
\hline Artemisia santolinifolia & $\mathrm{T}$ & . & & . & & . & . & & . & . & . & . & . & . & 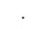 & G & . & A & & . & . & . & . & . & & . \\
\hline Artemisia kotuchovii & $\mathrm{T}$ & & G & . & . & . & & & . & . & . & . & . & . & T & . & 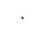 & A & A & G & . & . & . & . & c & \\
\hline Artemisia gmelinii & $T$ & & & & & & & & & & & & & & & & & A & & & & & & & & \\
\hline
\end{tabular}

Fig. 2. Polymorphic sites of Artemisia species detected in matK region. * Indicates specimens take from GenBank with their accession numbers. Endemic species for Kazakhstan are indicated in bold.

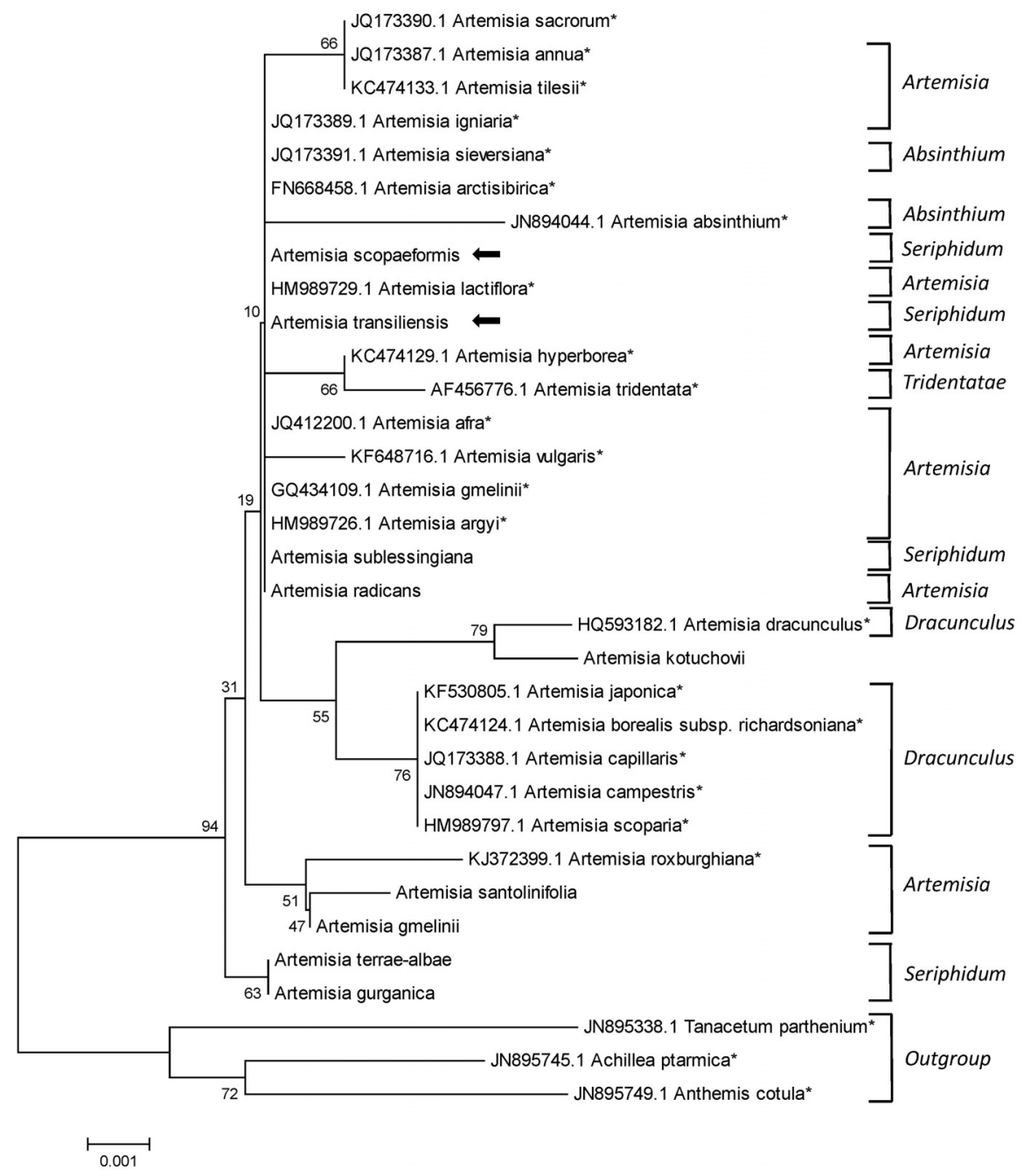

Fig. 3. Neighbour-joining phylogenetic tree results from the analysis of mat $\mathrm{K}$ sequences of nine local, twenty-one GenBank Artemisia species and three outgroup taxa. The subgenera classifications are given according to Poljakov, 1961. The lengths of branches are based on maximum composite likelihood and numbers at nodes shows a probability bootstrap. * denotes GenBank species with reference numbers from the NCBI database. Black arrows indicate endemic species.

Artemisia formed one large clade separately from outgroups. This Artemisia clade was further subdivided into four subclades. The first subclade included two local species (A. terrae-albae and A. gurganica) belonging to the 


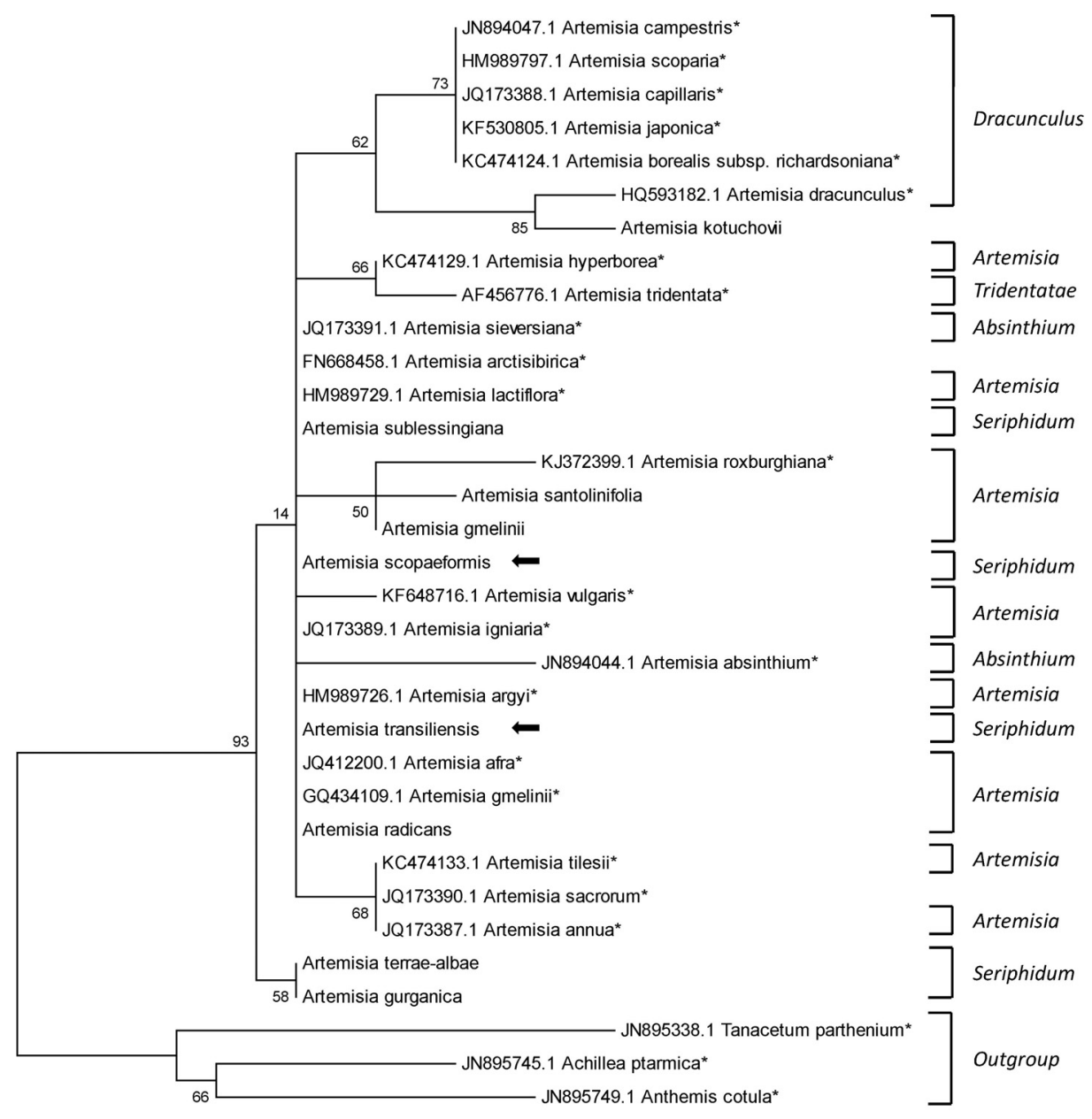

Fig. 4. Maximum parsimony phylogenetic tree reconstructed from the analysis of matK sequences of nine local, twenty-one GenBank Artemisia species and three outgroup taxa. The subgenera classifications are given according to Poljakov, 1961. The lengths of branches are based on maximum composite likelihood and numbers at nodes shows a probability bootstrap. * denotes GenBank species with reference numbers from the NCBI database. Black arrows indicate endemic species. subgenus Seriphidum. The next clade combined three species (A. gmelinii, A. santolinifolia, and A. roxburghiana) from the subg. Artemisia. The third subclade corresponded to the subg. Dracunculus and included all six species of this subgenus from GenBank. The local endemic species A. kotuchovii was also placed in this subclade. The last subclade was heterogeneous and represented four subgenera - Artemisia, Absinthium, Seriphidum, and Tridentatae.

The optimal MP tree was chosen from ten replicates (bootstrap 1000) for the same 33 species (Fig. 4) that had been studied using the NJ method. The generated tree showed different topology when it was compared to the NJ tree. In the MP tree all Artemisia species formed one major clade with two subclades apart from the outgroups. The first subclade was subgenus Dracunculus, which included A. kotuchovii. The second subclade was heterogeneous and included all other subgenera except Dracunculus.

The matK dataset, which combined both the GenBank and local accessions, was used for the network association analysis. The Network incorporated 33 species with 16 haplotypes clustering in six major haplotype lineages, which corresponded to five Artemisia subgenera and the outgroup (Table 2). Mean haplotype diversity for the set was relatively high $(\mathrm{Hd}=0.841)$, but nucleotide diversity was rather low $(\pi=0.0029, \mathrm{k}=2.211)$.
In order to compare topology of phylogenetic trees with the haplotype network, the studied nucleotide sequences combined in 16 haplotypes, including the outgroup, were analysed using Network 4.6. The obtained diagram shows consensus network with six groups of haplotypes corresponded to five subgenera and the outgroup cluster (Fig. 5). The largest haplotype H_6 in the centre of the diagram included 11 species from subg. Artemisia, Absinthium, and Seriphidum. The second largest haplotype was H_3, which contained five species from the subgenus Dracunculus, closely connected to A. kotuchovii in H_12. The haplotype H_9 was represented by A. tridentatea originated from the subg. Artemisia group, not supporting the theory of Seriphidum as the ancestor of the Tridentatae subg.

Phylogenetic and haplotype network analyses of local species. The second dataset was restricted to only nine $\mathrm{Ka}-$ zakhstan species and three outgroup taxa. This restricted dataset was also used for phylogenetic reconstruction by $\mathrm{NJ}$ and MP methods. Two trees showed very similar profiles for this dataset (Fig. 6 A, B). In both cases, subg. Artemisia species A. santolinifolia and A. gmelinii formed a separate subclade. A. kotuchovii was also placed apart from the others.

Local species sequences formed five haplotypes and were also used for median-joining network reconstruction (Table 
LIST OF HAPLOTYPES FORMED FROM THE ANALYSIS OF MATK GENE SEQUENCES OF LOCAL ARTEMISIA SPECIES, GENBANK SPECIMENS AND THE OUTGROUP

\begin{tabular}{|c|c|c|}
\hline Haplotype & $\begin{array}{l}\text { Number } \\
\text { of species }\end{array}$ & Species \\
\hline$\underline{\mathrm{H}} \_1$ & 1 & KJ372399.1 Artemisia roxburghiana* \\
\hline$\underline{\mathrm{H} \_2}$ & 1 & KF648716.1 Artemisia vulgaris* \\
\hline H_3 & 5 & $\begin{array}{l}\text { HM989797.1 Artemisia scoparia* } \\
\text { JN894047.1 Artemisia campestris* } \\
\text { JQ173388.1 Artemisia capillaris* } \\
\text { KC474124.1 Artemisia borealis subsp. } \\
\text { richardsoniana* } \\
\text { KF530805.1 Artemisia japonica* }\end{array}$ \\
\hline H_4 & 3 & $\begin{array}{l}\text { JQ173387.1 Artemisia annua* } \\
\text { JQ173390.1 Artemisia sacrorum }{ }^{*} \\
\text { KC474133.1 Artemisia tilesii }{ }^{*}\end{array}$ \\
\hline H_5 & 1 & $\begin{array}{l}\text { KC474129.1 Artemisia hyperborea* }{ }^{*} \text { (Artemisia } \\
\text { furcata) }\end{array}$ \\
\hline H_6 & 11 & $\begin{array}{l}\text { FN668458.1 Artemisia arctisibirica* } \\
\text { GQ434109.1 Artemisia gmelinii* } \\
\text { HM989726.1 Artemisia argyi* } \\
\text { HM989729.1 Artemisia lactiflora* } \\
\text { JQ173389.1 Artemisia igniaria* } \\
\text { JQ173391.1 Artemisia sieversiana* } \\
\text { JQ412200.1 Artemisia afra* } \\
\text { Artemisia radicans } \\
\text { Artemisia scopaeformis } \\
\text { Artemisia sublessingiana } \\
\text { Artemisia transiliensis }\end{array}$ \\
\hline$\underline{\mathrm{H}} \_7$ & 1 & JN894044.1 Artemisia absinthium* \\
\hline$\underline{\mathrm{H} \_8}$ & 1 & HQ593182.1 Artemisia dracunculus* \\
\hline$\underline{\mathrm{H}}$-9 & 1 & AF456776.1 Artemisia tridentata* \\
\hline H_10 & 2 & $\begin{array}{l}\text { Artemisia gurganica (Artemisia fragrans subsp. } \\
\text { gurganica Krasch.) } \\
\text { Artemisia terrae-albae }\end{array}$ \\
\hline$\underline{\mathrm{H} \_11}$ & 1 & Artemisia santolinifolia \\
\hline$\underline{\mathrm{H} \_12}$ & 1 & Artemisia kotuchovii \\
\hline$\underline{\mathrm{H} \_13}$ & 1 & Artemisia gmelinii \\
\hline$\underline{\mathrm{H} \_14}$ & 1 & JN895338.1 Tanacetum parthenium* \\
\hline$\underline{\mathrm{H}} \_15$ & 1 & JN895745.1 Achillea ptarmica* \\
\hline H_16 & 1 & JN895749.1 Anthemis cotula* \\
\hline
\end{tabular}

* indicates specimens taken from the GenBank with their accession numbers. Endemic species for Kazakhstan are indicated in bold.

3). Haplotype diversity for this set of data is $\mathrm{Hd}=0.806$, nucleotide diversity is $\pi=0.024, \mathrm{k}=1.889$. As a result, they were combined into two major groups corresponding to Artemisia and Seriphidum subgenera (Fig. 6 C). The largest haplotype H_1 includes four species, three of them belonged to Seriphidum and one's subgenus (A. radicans) is Artemisia. A. kotuchovii $\mathrm{H} \_4$ was placed separately from them, just like on phylogenetic trees.

\section{DISCUSSION}

Artemisia is one of the most complex genera and it is represented by the large number of species, diverse morphological types, ploidy and complicated genetic relationships

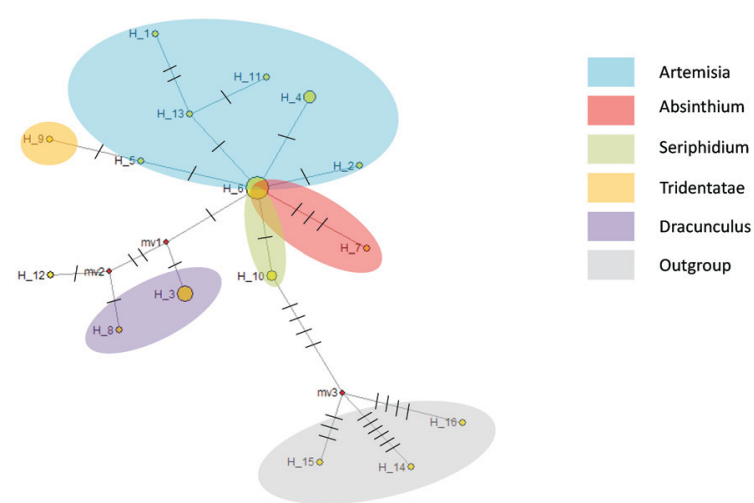

Fig. 5. Median-joining haplotype network. No MP criterion $(\varepsilon=0)$. Red small dots are median vectors presumed unsampled or missing intermediates. Yellow dots denote haplotypes; size is proportional to their frequencies. Number of perpendicular dashes on branches is equal to the number of mutations between two neighbouring dots. Colours denote the major groups based on subgeneric division. The subgenera classifications are given according to Poljakov, 1961.

(Winward and McArthur, 1995). Because of this, the clarification of the genus's taxonomy using classical botanical tools and morphological characteristics has many difficulties (Torrel et al., 1999). Therefore, usage of molecular markers is a valuable and promising addition to the traditional morphology-based classification. In this study, DNA barcoding approach based on the usage of matK marker was applied for the assessment of the Artemisia taxonomy of nine species collected in Kazakhstan. The analysis of the matK nucleotide sequences suggested that the marker provides sufficient information for differentiation of studied taxa. Generated NJ and MP trees of the studied taxa allowed to determine a single clade suggesting monophyletic origin of the genus, which was proposed earlier in the classical approaches (Torrel et al., 1999; Watson et al., 2002).

Previous molecular taxonomy studies with ITS using three main infrageneric groups of the genus (Dracunculus, Seriphidium, and Tridentatae) suggested that they have monophyletic origin, while the two remaining subgenera Absinthium and Artemisia appeared to be polyphyletic (Torrel et al., 1999; Sanz et al., 2008). Since the number of samples used in this study was limited, both NJ and MP phylogenetic trees only partially confirmed previously suggested taxonomic classification. For example, it is clearly visible, that the Dracunculus subclade is very distinct in both trees. A. terrae-albae and A. gurganica from subgenus Seriphidium formed the separate subclade distantly apart from the other species. Another outcome from the analysis of the phylogenetic trees was the taxonomy of less studied species - A. kotuchovii. The topology of both NJ and MP trees indicated that this species clearly belongs to the subgenus Dracunculus.

The haplotype networking diagram (Fig. 5) was rather more informative in comparison with the NJ and MP trees. First, the network analysis showed that haplotype H_6 was comprised from 11 species of subgenera Artemisia, Absinthium, and Seriphidium. Second, the H_6 was directly descendent 
A
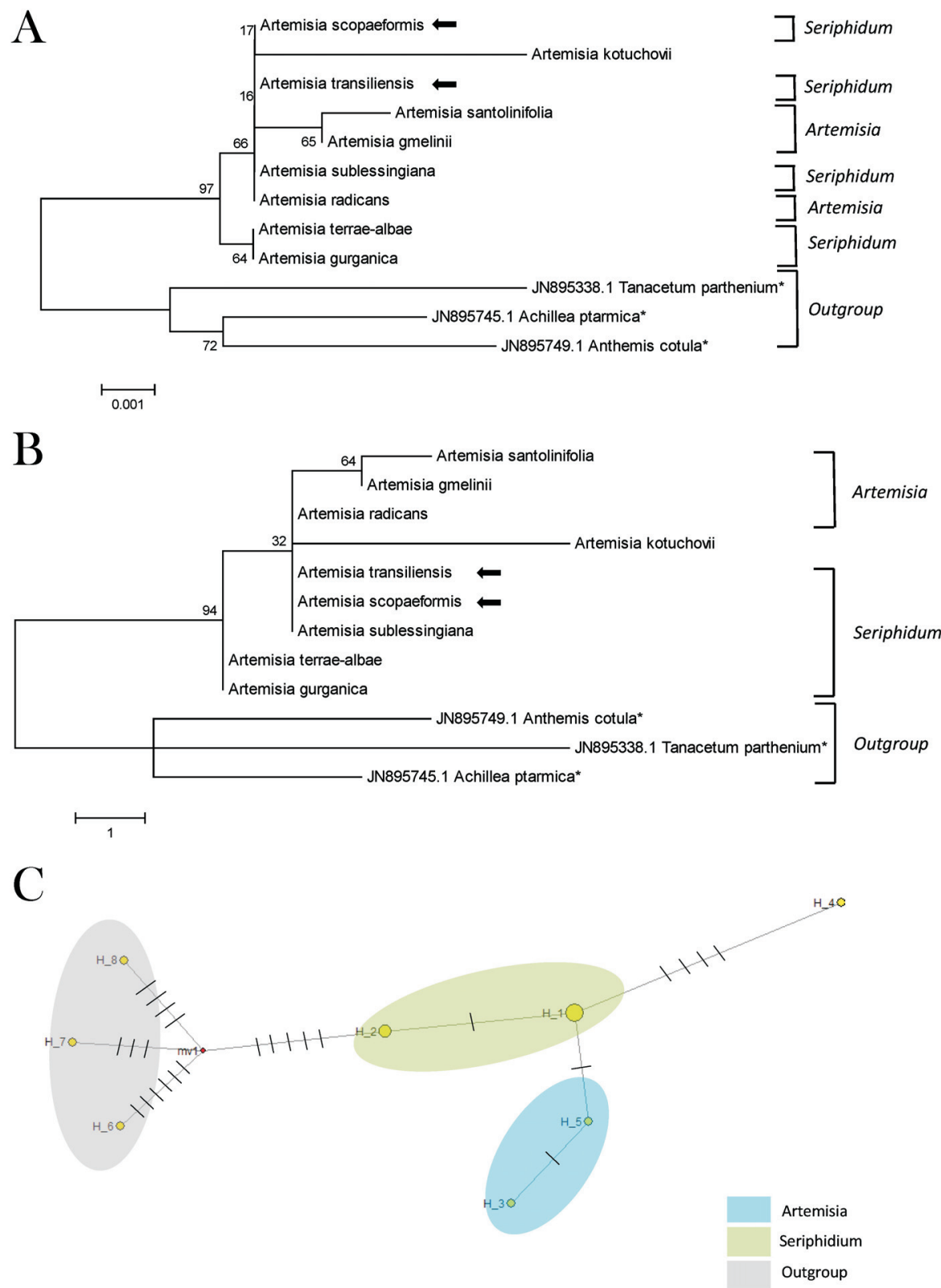

Fig. 6. Phylogenetic trees and the haplotype network based on the matK sequences of nine local Artemisia species and three outgroup taxa. A. Neighbour-joining phylogenetic tree. B. Maximum parsimony phylogenetic tree. C. Median-joining haplotype network. The subgenera classifications are given according to Poljakov, 1961. The lengths of branches are based on Maximum Composite Likelihood and numbers at nodes shows a probability bootstrap. * denotes GenBank species. Black arrows indicate endemic species. Red small dots are median vectors presumed unsampled or missing intermediates. Yellow dots denote haplotypes; size is proportional to their frequencies. Number of perpendicular dashes on branches is equal to the number of mutations between two neighbouring dots. Colours denote the major groups based on subgeneric division. from $\mathrm{H}_{-}$10, consisting of two species of subg. Seriphidium (Table 2). The presence of A. scopaeformis (Seriphidium) in H_6 makes sense because it logically connects these two haplotypes. Third, the haplotype $\mathrm{H} \_5$ consisted of only one species (A. hyperborea) in this study, which descended from H_6. Fourth, the haplotype H_9 descended from H_5, which suggests that the subgenus Tridentatae originated directly from species of subgenus Artemisia.

It is interesting that the network suggests three subgroups within the subgenus Artemisia. As the topology of the network suggests that $\mathrm{H}_{-} 13$ (A. gmelinii) is a predecessor of H_1 (A. roxburghiana) and H_11 (A. santolinifolia), it resembles the outcome from the MP tree (Fig. 4). The other outcome from the networking analysis is that haplotype H_7 (A. absinthium, Absintium) is directly connected to haplotype H_6, which is a reasonable connection because A. sieversiana (Absintium) is a part of this most frequent haplotype (H_6) in the study. Unlike in Absinthium, the haplotypes of Dracunculus (H_3 and H_8) are not connected to H_6 directly, but through intermediates mv1 and mv2, respectively (Fig. 5). As the mv2 connects A. dracunculus with A. kotuchovii, this confirms that this species belongs to the subg. Dracunculus.

In general, the analyses based on matK indicated that $A$. terrae-albae and A. gurganica from the subg. Seriphidium are predecessors of all other taxa within the genus Artemisia. Therefore, the conclusions based on the usage of plastid genome marker is not completely congruent with outcomes based on nuclear genome markers ITS (Torrels et al., 1999), as their parsimony analysis of 31 species resulted in a multifurcate type of the tree. Nevertheless, the authors indicated that the first clade of the tree was formed primarily from species of subg. Seriphidium. Later Watson with coauthors (Watson et al., 2002) analysed a larger number of 
Table 3

LIST OF HAPLOTYPES FORMED FROM THE ANALYSIS OF MATK GENE SEQUENCES OF LOCAL ARTEMISIA SPECIES AND THE OUTGROUP TAXA

\begin{tabular}{l|c|l}
\hline Haplotype & $\begin{array}{c}\text { Number } \\
\text { of species }\end{array}$ & \multicolumn{1}{c}{ Species } \\
\hline H_1 & 4 & $\begin{array}{l}\text { Artemisia radicans } \\
\text { Artemisia scopaeformis } \\
\text { Artemisia sublessingiana } \\
\text { Artemisia transiliensis }\end{array}$ \\
\hline H_2 & 2 & $\begin{array}{l}\text { Artemisia gurganica }(\text { Artemisia fragrans subsp. } \\
\text { gurganica } \text { Krasch.) } \\
\text { Artemisia terrae-albae }\end{array}$ \\
\hline H_3 & 1 & Artemisia santolinifolia \\
\hline H_4 & 1 & Artemisia kotuchovii \\
\hline H_5 & 1 & Artemisia gmelinii \\
\hline H_6 & 1 & JN895338.1 Tanacetum parthenium* $*$ \\
\hline H_7 & 1 & JN895745.1 Achillea ptarmica* \\
\hline H_8 & 1 & JN895749.1 Anthemis cotula* \\
\hline
\end{tabular}

* indicates specimens taken from the GenBank with their accession numbers. Endemic species for Kazakhstan are indicated in bold.

the genus Artemisia taxa consisting of 57 species of subtribe Artemisiinae from Old and New Worlds and pointed out on separation of subg. Dracunculus from all remaining Artemisia species. Therefore, one of the main conclusions in that study was the recognition of two subgenera within the Artemisia - subg. Dracunculus and an expanded subg. Artemisia (Watson et al., 2002). Phylogenetic trees and haplotype network generated using matK in this study hinted that the Dracunculus, although it is genetically a distinct subclade, descended from subg. Artemisia.

\section{CONCLUSIONS}

The application of phylogeny and haplotype network analyses indicated that some of the species of subgenus Seriphidium can be predecessors of the genus Artemisia. Specifically, A. terrae-albae and A. gurganica of this subgenus were closest to outgroup species used in this study. The haplotype network analysis was more informative in comparison to generated NJ and MP trees, as it is suggested a hypothetical evolutionary pathway within the genus. The network showed that the most frequent haplotype $\mathrm{H} \_6$ was common for three subgenera Artemisia, Absinthium, and Seriphidium. The species of subgenera Tridentatae derived from the species of Artemisia, whereas species of subgenera Dracunculus were distantly apart from the remaining species of the genus but via intermediate median vectors associated with the major haplotype H_6 of the genus Artemisia. Also, it was shown that the earlier unstudied species $A$. kotuchovii is a part of the subgenus Dracunculus.

\section{ACKNOWLEDGEMENTS}

The authors would like to acknowledge the funding from the Ministry of Education and Sciences of the Republic of Kazakhstan for national programme N0237.

\section{REFERENCES}

Adams, R. P., Turuspekov, Y. (1998). Taxonomic reassessment of some Central Asian and Himalayan scale-leaved taxa of Juniperus (Cupressaceae) supported by random amplification of polymorphic DNA. Taxon, 47, 75-84.

Aglarova, A. M., Zilfikarov, I. N., Severtseva, O. V. (2008). Biological characteristics and useful properties of tarragon (Artemisia dracunculus L.). Pharm. Chem. J., 42 (2), 81-86.

Anonymous (2017). National Center for Biotechnology Information. U.S. National Library of Medicine, Rockville Pike, 1988. Available from: https://www.ncbi.nlm.nih.gov (accessed 2 August 2017).

Bandelt, H. J., Forster, P., Röhl, A. (1999). Median-joining networks for inferring intraspecific phylogenies. Mol. Biol. Evol., 16 (1), 37-48.

Bhattacharyya, S., Mukherjee, J. (2017). IDXL: Species tree inference using internode distance and excess gene leaf count. J. Mol. Evol., 1-22.

Bremer, K. (1994). Asteraceae: Cladistics and Classification. Timber Press, Portland, Oregon. 752 pp.

Bremer, K., Humphries, C. (1993). Generic monograph of the AsteraceaeAnthemideae. Bull. Nat. Hist. Mus. Bot., 23, 1-177.

Bryant, C., Fischer, M., Linz, S., Semple, C. (2017). On the quirks of maximum parsimony and likelihood on phylogenetic networks. J. Theor. Biol., 417, 100-108.

Dellaporta, S. L, Wood, J., Hicks, J. B. (1983). A plant DNA mini preparation: Version II. Plant Mol Biol Rep., 1, 19-21.

Garcia, S., McArthur, E. D., Pellicer, J., Sanderson, S. C., Vallès, J., Garnatje, T. (2011). A molecular phylogenetic approach to western North America endemic Artemisia and allies (Asteraceae): Untangling the sagebrushes. Amer. J. Bot., 98 (4), 638-653.

Goryaev, M. I., Bazalitskaya, V. S., Poljakov, P. P. (1962). Chemical Composition of Artemisia. [Горяев, М. И., Базалицкая, В. С., Поляков, П. П. Химический состав польней.]. Academy of Sciences of KazSSR, Alma-ata. 153 pp. (in Russian).

Hebert, P. D. N., Gregory, T. R. (2005). The promise of DNA barcoding for taxonomy. Syst. Biol., 54 (5), 852-859.

Hebert, P. D., Cywinska, A., Ball, S. L., de Waard, J. R. (2003). Biological identifications through DNA barcodes. Proc. Biol. Sci., 270 (1512), 313-321.

Jun W, Nian-He X. (2012). Ardisia crenata complex (Primulaceae) studies using morphological and molecular data. In: Mworia, J. K. (Ed.). Botany. InTech, London, pp. 163-172.

Klayman, D. L. (1985). Qinghaosu (artemisinin): An antimalarial drug from China. Science, 228, 1049-1055.

Kornkven, A. B., Watson, L. E., Estes, J. R. (1998). Phylogenetic analysis of Artemisia section Tridentatae (Asteraceae) based on sequences from the internal transcribed spacers (ITS) of nuclear ribosomal DNA. Amer. J. Bot., 85 (12), 1787-1795.

Kress, W. J. (2017). Plant DNA barcodes: Applications today and in the future. J. Syst. Evol., 55, 291-307.

Kress, W. J., Erickson, D. L. (2007). A two-locus global DNA barcode for land plants: The coding $r b c L$ gene complements the non-coding trnH-psbA spacer region. PLOS ONE, 2 (6), e 508.

Lachenmeier, D. W. (2010). Wormwood (Artemisia absinthium L.) - a curious plant with both neurotoxic and neuroprotective properties? J. Ethnopharmacol., 131 (1), 224-227.

Li, X., Yang, Y., Henry, R. J., Rossetto, M., Wang, Y., Chen, S. (2015). Plant DNA barcoding: from gene to genome. Biol. Rev. Camb. Philos. Soc., 90 (1), 157-166.

Librado, P., Rozas, J. (2009). DnaSP v5: A software for comprehensive analysis of DNA polymorphism data. Bioinformatics, 25 (11), 1451-1452.

McArthur, E. D., Plummer, A. P. (1978). Biogeography and management of native western shrubs: A case study, Section Tridentatae of Artemisia. Great Basin Naturalist Memoirs, 2 (15), 229-243. 
Naeem, A., Khan. A. A., Cheema, H. M., Khan, I. A., Buerkert, A. (2014). DNA barcoding for species identification in the Palmae family. Genet. Mol. Res., 13 (4), 10341-10348.

Nikitina, E. V., Ubukeeva, A. U. (1964). Wormwoods of Kirghizia and Their Economic Importance. [Никитина, Е. В., Убукеева, А. У. Польни Киргизии и их хозяйственное значение.]. Academy of Sciences of KazSSR, Alma-Ata. 53 pp. (in Russian).

Oberpreiler, C., Vogt, R., Watson, L. (2003). Tribe Anthemideae. In: Kadereit, J., Jeffrey, C. (eds.). Families and Genera of Vascular Plants 8. Springer-Verlag, Berlin, pp. 342-374.

Obolskiy, D., Pischel, I., Feistel, B., Glotov, N., Heinrich, M. (2011). Artemisia dracunculus L. (tarragon): A critical review of its traditional use, chemical composition, pharmacology, and safety. J. Agric. Food Chem., 59 (21), 11367-11384.

Pavlov, N. V., Bykov, B. A., Goloskokov, V. P., Kubanskaya, Z. V. (eds.) (1966). Flora of Kazakhstan. Vol. 9. [Павлов, Н. В., Быков, Б. А., Голоскоков, В. П., Кубанская, 3. В. (ред.). Флора Казахстана, том 9.]. Nauka, Alma-Ata. 640 pp. (in Russian).

Persson, K. (1974). Biosystematic studies in the Artemisia maritima complex in Europe. Opera Bot. 35, 1-188.

Petrovska, B. B. (2012). Historical review of medicinal plants' usage. Pharmacogn. Rev. 6 (11), 1-5.

Poljakov, P. P. Artemisia L. genus. (1961). In: Komarov, V. L. Shishkin, B. K., Bobrov, E. G. (eds.) Flora of USSR. Vol. 26. [Комаров, В. Л., Шишкин, Б. К., Бобров, Е. Г. (ред.). Флора СССР, том 26.]. Academy of Sciences of the USSR, Leningrad, pp. 425-631 (in Russian).

Sanz, M., Vilatersana, R., Hidalgo, O., Garcia-Jacas, N., Susanna, A., Schneeweiss, G. M., Vallčs, J. (2008). Molecular phylogeny and evolution of floral characters of Artemisia and allies (Anthemideae, Asteraceae): Evidence from nrDNA ETS and ITS sequences. Taxon, 57 (1), 66-78.
Tamura, K., Stecher, G., Peterson, D., Filipski, A., Kumar, S. (2013). MEGA6: Molecular Evolutionary Genetics Analysis Version 6.0. Mol. Biol. Evol., 30 (12), 2725-29.

Tkach, N. V., Heinrich-Hoffmann, M., Korobkov, A. A., von Hagen K. B. (2008). Parallel evolutionary patterns in multiple lineages of arctic Artemisia L. Evolution, 62, 184-198.

Torrell, M., Garcia-Jacas, N., Susanna, A., Valles, J. (1999). Phylogeny in Artemisia (Asteraceae, Anthemideae) inferred from nuclear ribosomal DNA (ITS) sequences. Taxon, 48, 721-736.

Turuspekov, Y., Abugalieva, S. (2015). Plant DNA barcoding project in Kazakhstan. Genome, 58, 290.

Turuspekov, Y., Adams, R. P., Kearney, C. M. (2002). Genetic diversity of three perennial grasses from the Semipalatinsk nuclear testing region of Kazakhstan after long-term nuclear testing radiation exposure. Biochem. Syst. Ecol., 30, 809-817.

Valles, J., McArthur, E. D. (2001). Artemisia systematics and phylogeny: Cytogenetic and molecular insights. In: McArthur, E. D., Fairbanks, D. J. (comp.) Shrubland Ecosystem Genetics and Biodiversity: Proceedings, 13-15 June 2000, Provo, UT. Proc. RMRS-P-21. U.S. Department of Agriculture, Forest Service, Rocky Mountain Research Station, Ogden, UT, pp. $67-74$.

Wang, W. (2004). On the origin and development of Artemisia (Asteraceae) in the geological past. Bot. J. Linn. Soc., 145 (3), 331-336.

Watson, L. E., Bates, P. L., Evans, T. M., Unwin, M. M., Estes, J. R. (2002) Molecular phylogeny of subtribe Artemisiinae (Asteraceae), including Artemisia and its allied and segregate genera. BMC Evol. Biol., 2 (17).

Weathers, P. J., Arsenault, P. R., Covello, P. S., McMickle, A., Teoh, K. H., Reed, D. W. (2011). Artemisinin production in Artemisia annua: Studies in planta and results of a novel delivery method for treating malaria and other neglected diseases. Phytochem. Rev., 10 (2), 173-183.

Winward, A. H., McArthur, E. D. (1995). Lahontan sagebrush (Artemisia arbuscula ssp. longicaulis): A new taxon. Great Basin Naturalist, 55, 151-157.

\section{KAZAHSTĀNAS ARTEMISIA L. SUGU FILOĢENĒTISKĀ TAKSONOMIJA, PAMATOJOTIES UZ MATK ANALĪZI}

Tika sekvencēti matK gēni devin̄ām Kazahstānas Artemisia sugām, t.sk. endēmiskām. Tika apstiprināta monofiletiskā apakšğints Dracunculus izcelšanās. A. kotuchovii tuvums citām Dracunculus sugām norāda uz šīs sugas piederību minētai apakšǵintij. matK gēnu var veiksmīgi izmantot kā barkoda markieri Artemisia ğints izpētē. 